\title{
Rupture uterus - a cause of concern in rural medical college hospital in Assam
}

\author{
Jyan Dip Nath, Sulata Karmakar \\ Correspondence: Dr Sulata Karmakar, Registrar, Department of Obstetrics and \\ Gynaecology, FAA Medical College, Barpeta, Assam, Pin- 781301. Email - \\ nathknowledge@rediffmail.com \\ Distributed under Attribution-NonCommercial-ShareAlike 4.0 International (CC BY-NC-SA 4.0)
}

\begin{abstract}
Objective: The study is undertaken to find out the incidence, the cause of it, and the line of management and outcome of rupture uterus. Methodology: The entire patient diagnosed and treated from $1^{\text {st }}$ January, 2016 to $31^{\text {st }}$ December, 2016 are included. The detailed history, clinical examination, cause of rupture and line of management are recorded as per proforma. Result: Twelve numbers of cases were detected as rupture of uterus out of 7438 total deliveries and incidence of rupture uterus was $0.1 \%$. Out of them 7 cases were post caesarian (58.33\%), 3 cases were due to obstructed labour $(25 \%)$ and 2 cases had associated rupture bladder $(16.6 \%)$. Six cases had undergo subtotal hysterectomy $(50 \%)$ and 4 cases had repair $(33 \%)$. The outcomes of all the cases were satisfactory, all cases survived. Conclusion: The Rupture uterus is a matter of concern in obstetric practice. The post caesarian pregnancy and obstructed labour are the leading cause in our institution.
\end{abstract}

Keywords: Rupture uterus, scarred uterus, subtotal hysterectomy, repair.

The rupture uterus is a potentially life threatening condition to the mother and the foetus. Recently there is a shift of the cause from obstructed labour to post CS pregnancy. Therefore there is a cause of concern of increasing caesarian section (CS) in India. In India it still amounts to $2-10 \%$ of all maternal death, the perinatal mortality is $80 \%$ to $90 \%$. As per WHO, the incidence is 2.3 per 10000 deliveries worldwide ${ }^{1}$. However the incidence varies from 1 in 2581 to 1 in $10^{2,3}$. Out of different indications of obstetric hysterectomy, lateral rupture, colporrexis involving vagina or bladder, unrepairable rupture are the common reasons. The incidence of obstetrics hysterectomy from different reasons varies from $0.0779 \%$ to $0.38 \%{ }^{4,5 .}$. The aim of this study is to find out the incidence, cause, line of management and outcome of rupture uterus.

\section{Material and Method}

The study was carried out in the department of Obstetrics and Gynaecology in Fakhruddin Ali Ahmed Medical College, Bapeta from $1^{\text {st }}$ of January, 2016 to $31^{\text {st }}$ December of 2016. All cases diagnosed as complete uterine rupture, where entire thickness including the visceral peritoneum was ruptured were included in the study. The detailed history about antenatal and intranatal care with clinical examination was undertaken. The cases were resuscitated immediately with IV fluid, antibiotics, oxygen etc. The blood was collected from donor as per requirement. The possible investigations were done. The

Received: $14^{\text {th }}$ January 2018. Accepted: $13^{\text {th }}$ April 2018.

Nath J, Karmakar S. Rupture uterus - a cause of concern in rural medical college hospital in Assam. The New Indian Journal of OBGYN. 2019; 5(2): 79-82 
cases were put for laparotomy in presense of senior obstetrician under anaesthesia. Different operative procedures were performed as per age, parity and type of rupture. Close monitoring in post operative period was done of her vitals, infection, hydration, urinary output, anaemia etc. Adequate measures were taken in both the cases of bladder rupture, the help of surgeons were taken during operative and post operative period. The data were collected in the standard proforma and they were analyzed.

\section{Result and Observation}

The incidence of rupture uterus was $0.1 \%$ (12 out of 7438 total deliveries). There were $100 \%$ unbooked cases signifying the need for adequate antenatal care. Another significant factor is adolescent pregnancy, which was the

Table 1: Age, parity, other risk factors in rupture uterus $(\mathbf{N}-12)$

\begin{tabular}{lll}
\hline \multicolumn{2}{l}{ Variables } & Number (\%) \\
\hline Age in & $<20$ & $7(58.33 \%)$ \\
years & $20-25$ & $3(25 \%)$ \\
& $>25-30$ & $2(16.6 \%)$ \\
& $>30$ & - \\
\hline Parity & 0 & $2(16.6 \%)$ \\
& 1 & $6(50 \%)$ \\
& 2 & $1(8.33 \%)$ \\
& 3 & $2(16.6 \%)$ \\
& 4 & $1(8.33 \%)$ \\
& $\geq 5$ & - \\
\hline Risk & Post CS & $7(58.33 \%)$ \\
factors & Obstructed labour & $3(25 \%)$ \\
& History of D \& E & $1(8.33 \%)$ \\
& Adolescent pregnancy & $6(50 \%)$ \\
& Parity $\geq 3$ & $3(25 \%)$ \\
\hline
\end{tabular}

leading cause of rupture uterus with a number of 6 patients (50\%) (table 1) out of total 12 rupture uterus. It shows that child marriage is a significant risk factor for rupture uterus. It was seen that in 2 cases of primipara who had rupture uterus, 1 had history of previous D \& E and 1 had history of spontaneous abortion. Therefore, history of previous D\&E is another risk factor. However maximum number of rupture uterus was with parity $1(50 \%)$ but all of them were post CS. Therefore, there is a need of carefulness in deciding to do primary CS. While looking for the causes, the post CS pregnancy was the leading cause $7(58.33 \%)$ followed by obstructed labour $3(25 \%)$, History of D\&E was found in 1 case $(8.33 \%)$. In the management, subtotal hysterectomy was maximum with $6(50 \%)$ cases, the total hysterectomy in $2(16 \%)$ cases, and repair in $4(33.33 \%)$ cases (table 2). Additional

Table 2: Surgical Management of rupture uterus $(\mathrm{N}=12)$

\begin{tabular}{ll}
\hline Surgical management & No. of cases $(\%)$ \\
\hline Subtotal Hysterectomy & $6(50 \%)$ \\
Total Hysterectomy & $2(16.6 \%)$ \\
Repair & $4(33 \%)$ \\
Add Procedure- Bilateral tubal ligation & $1(8.33 \%)$ \\
Internal iliac artery ligation(bilateral) & $1(8.33 \%)$ \\
Bladder repair & $2(16.6 \%)$ \\
\hline
\end{tabular}

procedure were done like repair with bilateral tubal ligation in 1 case, subtotal hysterectomy with internal iliac artery ligation in 1 case, the bladder repair which were pre existing in 2 cases. There were no mortality, the success rate were $100 \%$.

\section{Discussion}

The rupture uterus is an obstetrics emergency with severe morbidity and possible mortality to the mother and with very high perinatal loss. The incidence of rupture uterus is given in table 3. The incidence was high as these are from underserved areas. Moreover there is lot of riverine areas with difficulty in accessing to health care

Table 3: Incidence of rupture uterus in different studies

\begin{tabular}{llll}
\hline Authors & Year & $\begin{array}{l}\text { No. of } \\
\text { cases }\end{array}$ & Incidence \\
\hline Padhye SM $^{5}$ & $1985-2000$ & 251 & $1: 1000$ \\
Ahmadi S et al $^{1}$ & $1989-1997$ & 28 & $1: 2581$ \\
Chatterjee S r et al $^{6}$ & $1995-2004$ & 40 & $1: 273$ \\
Sahu L $^{9}$ & $1995-2004$ & 253 & $1: 346$ \\
S S Choudhury $^{14}$ & $2011-2012$ & 24 & $1: 590$ \\
A Ehigiegbar et al $^{12}$ & $1991-2002$ & & $3.18 / 1000$ \\
I Dhaifalh et al $^{13}$ & & & $0.6 \%$ \\
Present study & Jan2016- Dec & 12 & $!: 620$ \\
& 2016 & & \\
\hline
\end{tabular}

facilities, resulting in transport delay. The cases were from low socio economic condition with poor literacy and ignorance. The child marriage was prevalent in this area. The antenatal care were inadequate, all were unbooked cases $(100 \%)$, which is comparable to the study of Radhakrishnan $(91.66 \% \& 80 \%)^{6}$. The cases arrived late in hospital. The age group is highest in below $20 \mathrm{yrs}$ 
(58.33\%), which highlight the ill effect of child marriage putting women at a higher risk. In the present study the parity was highest in 1- 4 parity $(83.33 \%)$, which is comparable with the findings of Ethigieba $\mathrm{AE}$ $(70.16 \%)^{7}$. Interestingly in this study two cases of primipara (16.6\%) with history of abortion were found which is comparable to Ojenuwah $(5.3 \%)^{8}$.

The significant finding of the present study is that the post CS pregnancy was the leading cause of rupture uterus $(58.33 \%)$ and it is comparable to Sahu $\mathrm{L}(50.1 \%)^{9}$, Sahin $\mathrm{Hg}$ et $\mathrm{al}(39,39 \%)^{10}$, Malik HS $(53.39 \%)^{11}$, A E Ehigieapar(68.2\% $)^{7}$, Zeteroglu S et al $(45 \%)^{12}$, I Dhaifaah $(48 \%)^{13}$, S S Choudhury et al $(41.66 \%)^{14}$. The incidence of obstructed labour is $25 \%$ in the present study which is comparable to Sameera Khan(26.6\%) ${ }^{15}$, Radhakrishnan (26.6\%) ${ }^{6}$, A E Ehigieapar(38.6\%) ${ }^{12}$, S S Choudhury et al (29.16\%) ${ }^{14}$ but higher in other studies like Israq Dhaifalah(83\%) ${ }^{13}$ and Chuni $\mathrm{N}(46.5 \%)^{16}$. The leading way of management is hysterectomy [subtotal hysterectomy (STH) - 50\%, total hysterectomy $-16.6 \%$ ] which is comparable to A E Ehigieapar et $\mathrm{al}(27 \%)^{7}$, S S Chaoudhury et al ${ }^{14}$ (STH + STH and internal iliac artery ligation - $41.66 \%$ ). The repair was done in $33.33 \%$ which is lower than study like Sameera Khan et al $20(52.9 \%)$, S A Ojenuwah $(50 \%)^{8}$, S S Choudhury et al $(50 \%)^{14}$. The repair is lower in our study because they arrived late. As this area is a rural underserved area with lot of riverine areas the transportation was difficult. Moreover the poverty, illiteracy, ignorance, and lack of health care we found a lot of difficult cases. Munro Kerr's advice for internal iliac artery ligation in grave condition and it was done in one case. Boy in 1962 advocated hysterectomy as the mortality is high in repair cases because toxins are absorbed and the some devitalized tissue remains inside the abdomen. In our series, there is no morality but in the study where repair is high, the mortality is reported as in the study of S S Choudhury (1 case) ${ }^{14}$.

\section{Conclusion}

The rupture of uterus is still a challenging task in practice of obstetrics with severe morbidity and possible mortality, Therefore the emphasis should be given in prevention, early detection, early referral and prompt management. The rise of general CS rate with consequent increase of post CS rupture is a matter of concern. Therefore the primary CS should not be one for trivial cause like request, supposed prolongation of labour. Moreover the patient and party must be counseled at the time of discharge, that the next delivery must be done in a well equipped hospital alongwith frequent antenatal care, otherwise rupture uterus may occur. The rupture of uterus is a preventable cause to a large extent and its prevention can save lives.

\section{Conflict of interest: None. Disclaimer: Nil.}

\section{References}

1.WHO systemic review of motility and morbidity: the prevalence of rupture uterus. BJOG. 2005; 172:1221-28.

2.Ahmadi S, Nouria M, Bibi M. Uterine rupture of the unscarred uterus, about 28 cases. Gynecol Obstet Fertil. 2003; 31(9): 713-7.

3.Ofir K, Sheiner E, Levy A. Uterine rupture: Risk factor and pregnancy outcome. Obstet Gynecol 2003;189:1042-6.

4.Devi P, Singh RK, Singh D. Emergency Obstetric hysterectomy. J Obstet Gyneco India. 2004; 54:343-5.

5.Sinha H, Mishra M. Hysterectomy for obstetrics emergency. J Obstet Gynecol India. 2001; 51: 111-4.

6.Radhakrishnan G, Rashmi, Vaid NB, Agarwal N. Rupture uterus changing India scenario. J Indian Medical Association. 2001; 99(11): 634-7.

7.Ehigiegha AE, Adeyemo IS. Uterine rupture in Labour a continuing obstetric challenge in developing countries-the Benin Experience. J Med Biomed Research. 2006; 5(1):4450 .

8. Ojenuwah SA, Olowosulu RO. Surgical management of rupture uterus in BIDA, North Central Nigeria. Tropical Doctor. 2007; 37: 219-21.

9. Mahapatra U. Rupture of Gravid uterus in secondary care hospital. Rural Surgery. 2005:1(4):10-11.

10.Sahin HG, Kolusari A, Yildizhan R, Kurdoglu M. Uterine rupture: A twelve year analysis. J Matern Fetal Neonatl Med. 2008; 21: 503-6.

11.Malik HS. Frequency, predisposing factors and fetomaternal outcome in uterine rupture. J Coll physicians surg Pak. 2006; 16: 472-5. 
12.Zeteroglu S, Ustun Y, Engin U, Sahin HF, Kamaci M. Eight years experience of rupture uterus cases. J Obstet Gynecol. 2005; 25(5): 458-61

13.Dhaifalah I, Santavy J, Fingerova H. Uterine rupture in pregnancy and delivery among women attending the Althawra Hospital in Sana - A city Yemen Republic. Biomed Pap Med Fac Univ Palacky Olomonic Czech Republic. 2006; 150: 279-83.

14.Choudhury SS, Choudhury B, Deka G. Rupture uterus incidence and management in a tertiary centre in Assam. The New India Journal of OBGYN. 2017; 4(1): 77-9.

15.Khan S, Parveen Z, Begum S, Alam I. Uterine rupture, a review of 34 cases at Ayab teaching hospital, Abbottabad
[Internet]. 2002 (cited 2017 Jan 10). Available from http: //www. Aybmed. edu,pk/ JAMC/ PAST/15-4/sameera.htm

16.Chuni N. Analysis of uterine rupture in a tertiary centre eastern Nepal - lessons for obstetric care. J Obstet Gynaecol Res. 2006; 32(6): 574-9.

Jyan Dip Nath ${ }^{1}$, Sulata Karmakar ${ }^{2}$

${ }^{1}$ Associate Professor, ${ }^{2}$ Registrar; Department of Obstetrics and Gynaecology, FAA Medical College, Barpeta, Assam, India. 